\title{
Strategic Sourcing: A Comparative Study across Two Industries
}

\author{
Burhan F. Yavas, Ph.D. (Corresponding author) \\ Professor and Chair, Department of Accounting, Finance \& Economics \\ California State University Dominguez Hills \\ 1000 East Victoria Street, Carson, CA 90747, USA \\ Tel: 1-310-243-3501Ｅ-mail: Byavas@csudh.edu \\ G Keong Leong \\ Chair, Department of Management, Professor of Management \\ University of Nevada, Las Vegas \\ 4505 Maryland Pkwy Box 456009, Las Vegas, NV 89154, USA \\ E-mail: Keong.leong@unlv.edu \\ Demosthenes Vardiabasis, Ph.D. \\ Professor of Economics, Pepperdine University \\ 24255 Pacific Coast Highway, Malibu, CA 90263-7493, USA \\ E-mail: Dvardiab@pepperdine.edu \\ Natasa Christodoulidou, Ph.D. \\ Assistant Professor of Marketing \\ California State University Dominguez Hills \\ 1000 East Victoria Street, Carson, CA 90747, USA \\ E-mail: Nchristodoulidou@csudh.edu
}

Received: September 8, $2010 \quad$ Accepted: October 23, $2010 \quad$ doi:10.5539/ijbm.v6n4p3

\begin{abstract}
The purpose of the present investigation is to examine the perceptions of managerial practices regarding issues surrounding strategic sourcing (SS) across different industries. The two industries examined in this study are the manufacturing and the service industries. Although arguably these industries are different in terms of industry practices and culture there has been a trend toward convergence of managerial practices. Major items such as VMI, education, risk assessment, and social responsibility appear to have the same importance in both the manufacturing and service industry. The findings also indicate some support for the divergence view. Issues such as diversity, collaboration in reducing costs, and communication with upper management, exhibit some differences in opinion among manufacturing executives and service oriented executives. These differences may be attributed to the services industry still being in its infancy stage in the sourcing arena. This can have implications for both industries as they are becoming more hybrid in nature and at times becomes challenging to distinguish between a good or a service.
\end{abstract}

Keywords: Strategic Sourcing, Diverging vs Converging managerial perceptions regarding sourcing

\section{Introduction}

To compete globally, companies need to do pay close attention to various components of their value chain. Links in the chain include primary activities; R \& D, product (service) quality, marketing \&customer service as well as secondary activities of Information Technology (IT), supply chain management, Human Resources (HR) and 
sourcing. An important source of competitive advantage is based on strategic sourcing and this is the focus of the present paper.

In what follows, we compare the components of a strategic sourcing model across two different industries: manufacturing and services. In this comparison we expect to understand features of strategic sourcing model which are shared across different industries and features that are unique to each industry. Closer interaction, technological progress and competition appear to be helping reduce cross industry differences and hence the attitudes of manufacturing and service industry managers are becoming more similar. Thus, if the strategic sourcing model (SSM) is invariant across the two industries, this provides support for the converging managerial practices. If the model does show variance across the two industries, and this variance appears to coincide with managerial differences, this provides support for the diverging approach. Thus, the research questions to be investigated are: Do managers from two different industries respond to a set of strategic sourcing items in a manner that results in similar dimensions of SSM? Are the responses to these items similar across the two industries?

A questionnaire was used to gather data for the study. To help develop the survey, a literature search was conducted and sourcing managers were interviewed. Data were collected from sourcing managers recruited through personnel departments of various organizations within each industry. Qualifications for inclusion in the study are that the individual be in a managerial position and be willing to complete the Strategic Sourcing Questionnaire Two thousand two hundred forty were mailed and/or hand delivered to the companies in the sample, followed by e-mail inquiries. A total of 133 surveys were returned and used to analyze the data. All of the companies in the study but one are based in the United States.-

\section{Literature Review (see Table 1)}

Company wide integration of supply chain initiatives is important to an organization (Carr and Pearson, 1999; Ellram et al., 2002, Katz et al., 2003). Other areas within an organization view managing strategic sourcing as an important function (Carter and Narasinham, 1996; Ellram et al., 2002; Zsidsin et al., 2003). Sourcing goals are usually well understood and visible throughout the entire organization (Ellram et al., 2002; Zsidsin et al., 2003). Education regarding supply chain dynamics is also important to an organization (Carter and Narasimhan, 1996; Nelson et al., 1998).

Total Cost of Ownership (TCO), also plays a key role in strategic sourcing: Strategic sourcing performance objectives are based on TCO, and TCO is a well-understood and accepted measurement tool used by the organization and by strategic sourcing management (Ellram and Siferd, 1998; Ellram et al., 2002; Ellram and Siferd, 2003; Zsidsin et al., 2003). Often, key supplier selection decisions are based on TCO rather than on price (Ellram and Siferd, 1998; Degraeve and Roofhooft, 1999, Ellram et al., 2002; Ellram and Siferd, 2003; Zsidsin et al., 2003). The cost of diversity selection (i.e., the cost of diversity integration) is included in TCO (Adobor and McMuller, 2007; Whifield and Landeros, 2006; Shah and Ram, 2006). The cost of environmental innovation (cost of sustainability) is also a part of TCO (Gonzalez-Padron et al., 2008). Supplier ethics is an important issue when determining TCO (Gunlach and Murphy, 1993; Landeros and Frank, 1996; Carter, 2000 \& 2005; Cooper et al., 2000; Carson, 2003; Fassin, 2005; Bendixen et al., 2007; Integrity Interactive, 2007; Gonzalez-Padron et al., 2008).

In analyzing a supplier structure, one consideration is the breakdown of a supplier's cost structure for key purchases (Zsidsin et al., 2003, Kremic et al, 2006). Strategic sourcing management works with suppliers to encourage them to disclose their costs and cost structures (Carter and Narasimhan, 1996; Ellram, 1996; Ellram et al., 2002; Zsidsin et al., 2003). Strategic sourcing management and suppliers then work together to reduce the costs of products and services (Ellram et al., 2002; Zsidsin et al., 2003; Cousineau et al., 2004; Bendixen et al., 2007). Business relationships between suppliers and strategic sourcing management are also important to the organization (Gunlack and Murphy, 1993; Newman and McKeller, 1995; Carter and Narasimhan, 1996; Carr and Pearson, 1999; Peck and Payne, 2000; Sarkis and Tulliri, 2002; Ellram et al., 2002; Ryder and Fearne, 2003; Zailani and Rajagopal, 2005; Bendixen and Abratt, 2007; Bendixen et al., 2007; Gonzalez, Padron et al., 2008). Vendor certification can be used as a guide for developing relationships (Carter and Narasimham, 1996). Finally, reducing the supplier base is important in strategic sourcing and supplier relationships (Degraeve and Roodhooft, 1999).

VMI may be defined as a strategy between the vendor and the customer that aims to reduce the inventory at the customer's site while at the same time minimizing the cost for the two companies involved in making the inventory available (Hines, 2000). In VMI, the responsibility for managing a customer's inventory is transferred from the customer to the supplier (Elvander et al., 2007). In addition, the vendor decides "the appropriate 
inventory levels of each of the products and the appropriate inventory policies to maintain those levels" (Sari 2007, p.530). The supplier takes responsibility for the operational management of the inventory within a mutually agreed framework of performance targets which are constantly monitored and updated to create an environment of continuous improvement. Since the supplier assumes the role of replenishing the customer's products, the result can be lower costs associated with monitoring and ordering inventory for the customer (Sari, 2007). When VMI is used the supplier is routinely responsible for managing inventories for the customer (Dong et al., 2007; Danese, 2006; Cetinkaya and Lee, 2000). With its focus on partnership and information sharing, VMI has emerged as a significant trend in partnership and information sharing in supply chain management (Mishra and Raghunathan, 2004). Moreover, its information sharing component can result in tremendous performance improvements for the supply chain (Sari, 2007). For example, when physical inventory is reduced so is the need for storage space. Likewise, when the usage site is the storage site the cost of moving material from the warehouse to the actual usage site is reduced (Yao et al., 2007). Cost savings also improve as ordering costs are reduced through VMI. The overall goal of VMI is to efficiently manage inventory in the supply chain (Schor, 1998; Elvander et al., 2007).

Quality is also a crucial part of the strategic sourcing concept (Newman and McKeller, 1995; Carter and Narasimhan, 1996; Kaynak, 1997; Degraeve and Roodhooft, 1999, Ting and Cho, 2008). In addition, on-time delivery is another issue when the firm participates in off shoring (Stringfellow et al., 2007) or global sourcing (Zeng, 2003). In strategic sourcing, off shoring involves dealing with customs and duties and as such these issues can have an impact on costs and efficiencies (Richter, 2002).

\section{Methodology and Analysis}

Using a sample of 129 survey respondents, the survey responses were analyzed using the statistical software SAS. 56 respondents were from the manufacturing industries and 73 from the service industries.

Data were grouped into Manufacturing and Services industries. Group numerical averages for each item were calculated. These averages were then correlated between the two groups. Between group t-tests were also conducted on all of the items in the questionnaire. These t-tests helped determine whether the two groups differed in their responses on strategic sourcing.

The between group correlation coefficient for all items was .47 (correlation coefficient ranges from zero to one,; values close to zero indicate no correlation while values close to one indicate high correlation).

Table 2 below summarizes the data. Responses of 1, 2 and 3 are added together well as the responses of 5,6 and 7. Percentage response distribution is indicated in table 2.

Question 1 indicators

$1=$ Much Worse

$2=$ Worse

$3=$ Slightly Worse

$4=$ Same

$5=$ Slightly Better

$6=$ Better

$7=$ Much Better

Questions 2-35 indicators

$1=$ Strongly Disagree

$2=$ Disagree

3-Somewhat Disagree

$4=$ Neutral

$5=$ Somewhat Agree

$6=$ Agree

$7=$ Strongly Agree

Tables 3 and 4 detail the results of between group t-tests conducted for determining whether the two group means are different. A cutoff value of $\mathrm{p}<0.05$ (or 5 percent significance level) is used to distinguish between converging and diverging views on sourcing. Accordingly, table 3 consists of those items for which the 
perceptions of the two groups do not differ significantly ( $>0.05$ ) and Table 4 reports those survey items on which there are significant differences $(p<0.05)$.

\section{Findings}

There were quite a few similarities in the perceptions of manufacturing and service industry managers. Both groups closely agree on the importance of sourcing strategy supporting overall corporate strategy. Both groups see Vendor Managed Inventory (VMI) as an important component of strategic sourcing and agree that strategic goals are well understood throughout their organizations. Further, there is a shared belief regarding the importance education, social responsibility and supplier reliability.

Similar results are found with respect to risk assessment and total cost of ownership. With respect to the latter, while managers are in agreement that total cost of ownership is well-understood within the organization and performance objectives in sourcing are based on total cost of ownership, there were some differences on whether TCO was well-articulated within the sourcing function. There was also agreement on key supplier selection decisions being based on total cost of ownership rather than price. In addition, respondents agree on the cost of environmental innovation is included in the total cost of ownership as well as Supplier Ethics Management (SEM) is an important component of sourcing in determining total cost of ownership. This indicates that these practices are converging rather than diverging.

Other items of agreement include the following:

- Supplier relationships are important to the organization. This is in full alignment with the literature where business relationships are of upmost importance in an organization. This has been gaining importance in the literature back in the 1990s with a number of articles focusing on it in the late 2000s (Gunlack and Murphy, 1993; Newman and McKeller, 1995; Carter and Narasimhan, 1996; Carr and Pearson, 1999; Peck and Payne, 2000; Sarkis and Tulliri, 2002; Ellram et al., 2002; Ryder and Fearne, 2003; Zailani and Rajagopal, 2005; Bendixen and Abratt, 2007; Bendixen et al., 2007; Gonzalez, Padron et al., 2008).

- Quality is an important component in sourcing. Quality appears to be equally important to the manufacturing as well as to the services industry. This finding is most likely part of the trend of the last decade where consumers have become more demanding when it comes to quality. This may be due to the fact that the internet has made it easier to conduct research on an item or a service and hence make quality more comparable and transparent.

- Reducing the supplier base is important in sourcing. Reducing the supplier base in sourcing may lead to increased cost savings due to economies of scale; naturally this applies to both manufacturing and services.

- Off shoring is an important component of determining costs. With the explosion of off shoring and outsourcing abroad various items and services, it is expected that this will increase further in the future. In the United States, many services related to technology and customer service orientation have been vastly moved overseas, primarily in English speaking countries such as India.

- Sourcing historically has been able to track records of purchases and projections as to make the field viable, transparent, and profitable. This may contribute to the agreement that was exhibited in the survey results for the following items:

- Sourcing management has cost targets for purchases based on the projected selling price and profit goals for the organization's new products/services.

- Sourcing management has cost targets for purchases based on the projected selling price and profit goals for the organization's existing products and services.

- Sourcing management develops a database of estimated supplier cost structures to use when needed (sometimes referred to as cost tables).

Based on the results indicated above, there is support that the SSM is invariant across the two industries and thus provide support for the converging managerial practices. However, table 4 shows there are some significant differences. These relate to whether articulated strategies were developed by sourcing management, whether the sourcing component is accountable, and communicating goals and performance as well as cost savings to the top management while managers and executives are in agreement that Total Cost of Ownership (TCO) is well-understood within the organization and performance objectives in sourcing are based on TCO, they differ whether TCO was well-articulated within the sourcing function. These differences may be attributed to sourcing 
(or purchasing) as a disciple is still in its infancy stage.

Other areas of disagreement include the following:

- Sourcing management and suppliers work together to take costs out of products and services. It appears that in manufacturing sourcing managers work more often with suppliers to reduce costs rather than in the service industry. This may be attributed to the fact that in manufacturing often the cost distribution is more transparent than for services.

- Sourcing management goals and actual performance are reported to top management. Sourcing has had a longer history in the manufacturing industry rather than in the service industry. This may account for sourcing executives having a "tradition" to report the goals and performance to top management rather than the sourcing executives in the service industry. This also may account for the cost of diversity in supplier selection included in the TCO; the establishment of sourcing in manufacturing may contribute to this particular cost.

Based on the above findings, this SSM supports that there is both a divergent and a convergent momentum in sourcing practices in these two industries.

\section{Limitations}

It should be noted that in some instances the sample includes multiple respondents from the same firm, thus it could be argued that responses are not independent since they may be influenced by the firm's approach to sourcing. Given the non company-specific nature of most of the questions, however, it may not make a big different in this case.

\section{Conclusions}

Are manufacturing and service industry managers' perceptions converging or diverging? The study's findings suggest that their attitudes are converging. However, we have also found some support for the divergence view. For example issues such as diversity, collaboration in reducing costs, and communication with upper management, exhibit some differences in opinion among manufacturing executives and service oriented executives. These differences may be attributed to the services industry still being in its infancy stage in the sourcing arena.

Overall, this study mostly supports that the perceptions are more similar than different. Major items such as VMI, education, risk assessment, and social responsibility have the same importance in both the manufacturing and service industry. This can have implications for both industries as they are becoming more hybrid in nature and at times becomes challenging to distinguish between a good or a service.... With perceptions being more similar, it may make it easier for sourcing executives to move between industries and suppliers having fewer challenges in working with sourcing managers across a diverse range of industries.

\section{References}

Adobor, H, \& McMullern, R. (2007). Supplier Diversity and Supply Chain Management: Strategic Approach. Business Horizons, 50, 219-29.

Bendixen, M., \& Abratt, R. (2007). Corporate Identity, Ethics, and Reputation in Supplier Buyer Relationships. Journal of Business Ethics, 76, 69-82.

Bendixen, M., Abratt, R., \& Jones, P. (2007). Ethics and Social Responsibility in Supplier-Customer Relationships. Journal of Applied Management and Entrepreneurship, 12, 3-23.

Carr, A.S., \& Pearson, N.J. (1999). Strategically Managed Buyer-Supplier Relationships and Performance Outcomes. Journal of Operations Management, 17, 497-519.

Carr, A.S., \& Smeltzer, L.R. (1999). The Relationship among Purchasing Benchmarking, Strategic purchasing, Firm Performance, and Firm Size. Journal of Supply Chain Management, 35, 199-207.

Carson, T.L. (2003). Self-interest and business ethics: Some lessons of the recent corporate scandals. Journal of Business Ethics, 43, 389-94.

Carter, C.R. (2000). Precursors for unethical behavior in global supplier management. Journal of Supply Chain Management, 36, 45-56.

Carter, C.R. (2005). Purchasing social responsibility and firm performance: The key mediating roles of organizational learning and supplier performance. International Journal of Physical Distribution \& Logistics Management, 35, 177-194. 
Carter, J.R., \& Narasimhan, R. (1996). Is Purchasing Really Strategic? International Journal of Purchasing and Materials Management, 32, 20-28.

Cetinkaya, S., \& Lee, C. (2000). Stock Replenishment and Shipment Scheduling for Vendor-Managed Inventory Systems. Management Science, 46, 218-32.

Cooper, R.W., Frank, G.L., \& Kemp, R.A. (1997). The ethical environment facing the profession or purchasing and materials management. International Journal of Purchasing and Materials Management, 3, 2-11.

Cooper, R.W., Frank, G.L., \& Kemp, R.A. (2000). A multinational comparison of key ethic issues, helps and challenges in the purchasing and supply management profession: The key implications for business and the professions. Journal of Business Ethics, 23, 83-100.

Danese, P. (2006). The extended VMI for coordinating the whole supply network. Journal of Manufacturing Technology Management, 17, 888-907.

De Toni, A.F., \& Zamolo, E. (2005). From a traditional replenishment system to vendor managed inventory: A case study from the household electrical appliances sector. International Journal of Production Economics, 96, 63-79.

Degraeve, Z., \& Roodhooft, F. (1999). Effectively Selecting Suppliers using Total Cost of Ownership. Journal of Supply Chain Management, 35, 5-10.

Disney, S.M., \& Towill, D.R. (2002). A discrete transfer function model to determine the dynamic stability of a vendor managed inventory supply chain. International Journal of Production Research, 40, 179-204.

Dong, Y., Xu, K., \& Dresner, M. (2007). Environmental determinants of VMI adoption: An Exploratory analysis. Transportation Research, 43, 355-69.

Ellram, L.M. (1996). A Structured Method for Applying Purchasing Cost Management Tools. International Journal of Purchasing and Materials Management, 32, 11-19.

Ellram, L.M., \& Siferd. S.P. (1998). Total cost of ownership: a key concept in strategic cost management decisions. Journal of Business Logistics, 19, 55-84.

Ellram, L.M., \& Siferd, S.P. (1993). Purchasing: The Cornerstone of the Total Cost of Ownership Concept. Journal of Business Logistics, 14, 163-84.

Ellram, L.M., Zsidsin, G.A., Siferd, S.P., \& Stanley, M.J. (2002). The impact of purchasing and supply chain management activities on corporate success. Journal of Supply Chain Management, 38, 4-17.

Elvander, M.S., Sarpola, S., \& Mattsson, S. (2007). Framework for characterizing the design of VMI systems. Journal of Physical Distribution and Logistics Management, 37, 782-98.

Fassin, Y. (2005). The reasons behind non-ethical behavior in business and entrepreneurship. Journal of Business Ethics, 60, 265-79.

Ferrin, B.G., \& Plank, R.E. (2002). Total Cost of Ownership Models: An Exploratory Study. Journal of Supply chain Management, 38, 18-29.

Gonzalez-Padron, T., Hult, T.G., \& Calantone, R. (2008). Exploiting innovative opportunities in global purchasing: An assessment of ethical climate and relationship performance. Industrial Marketing Management, 37, 69-82.

Gumus, M., Jewkes, E., \& Bookbinder, J. (2007). Impact of consignment inventory and vendor-managed inventory for a two-party supply chain. International Journal of Production Economics, 113, 502-17.

Gunlach, G.T., \& Murphy, P.E. (1993). Ethical and Legal Foundations of Relational marketing Exchanges. Journal of Marketing, 57, 35-46.

Hines, P., Lamming, R., Jones, D., Cousins, P., Rich, N. (2000). Value Stream Management Strategy and Excellence in the Supply Chain, Financial Times, Englewood Cliffs, NJ: Prentice-Hall.

Integrity Interactive. (2007). Global Attitudes \& Best Practices in Ethics \& Compliance Risk Management, Boston, MA.

Katz, J.P., Pagell, M.D., \& Bloodgood, J.M. (2003). Strategies of supply communities. Supply Chain Management: An International Journal, 8, 291-302.

Kaynak, H. (1997). Total Quality Management and Just-in-Time Purchasing: Their Effects on Performance of Firms Operating in the U.S., New York, NY. 
Landeros, R., \& Frank, R.E. (1996). How ethical are purchasing management professionals? Journal of Business Ethics, 15, 789-803.

Mishra, B.K., \& Ranghunathan, J. (2004). Retailer vs. Vendor-Managed Inventory and Brand Competition", Management Science, 50, 445-57.

Nelson, D., Mayo, R., \& Moody, P.E. (1998). Powered by Honda; Developing Excellence in the Global Enterprise, New York. NY: Wiley.

Newman, R., \& McKleer, J.M. (1995). Target Pricing-A Challenge for Purchasing. International Journal of Purchasing and Materials Management, Vol.31 No.3, pp.13-20.

Peck, H., Payne, A., Christopher M., \& Clark, M. (2000). Marketing strategy and implementation, Oxford: Butterworth-Heinemann.

Sarkis, J., \& Tulluri, S. (2002). A Model for Strategic Supplier Selection. Journal of Supply Chain Management, $38,18-28$.

Schmidgall, R. S., \& Damitio, J. W. (2006). Hospitality Industry Financial Accounting. Educational Institute of the American Lodging Association.

Schorr, J.E (1998). Purchasing in the 21st Century: A Guide to State-of-the-Art Techniques and Strategies. New York: Wiley.

Stringfellow, A., Teagarden, M.B., \& Nie, W. (2007). Invisible costs in off shoring services work. Journal of Operations Management, 26, 164-79.

Walker, G., \& Weber, D. (1984). A transaction cost approach to make-or-buy decisions. Administrative Science Quarterly, 29, 373-92.

Whifield, G., \& Landerons, R. (2006). Supplier Diversity Effectiveness: Does Organizational Culture Really Matter? Journal of Supply Chain Management, 42, 17-29.

Wisner, J.D., Leong, K.G., \& Tan K. (2005). Principles of Supply Chain Management: A Balanced Approach, Mason, $\mathrm{OH}$ : Thomson South-Western.

Yao, Y., Evers, P.T., \& Dresner, M.E. (2007). Supply chain integration in vendor-managed inventory. Decision Support Systems, 43, 663-74.

Zailani, S. (2005). Supply chain integration and performance: US versus East Asian companies. Supply Chain Management: An International Journal, 10, 379-393.

Zsidisin, G., Ellram, L.M., \& Ogden, J. (2003). The Relationship between Purchasing and Supply Management's Perceived Value and Participation in Strategic Supplier Cost Management Activities. Journal of Business Logistics, 24, 129-54. 
Table 1. Strategic Sourcing in the Global Manufacturing and Service Industry

\begin{tabular}{|c|c|c|}
\hline Group & Question & Adopted from: \\
\hline \multirow[t]{5}{*}{$\begin{array}{l}\text { Strategic Integration within } \\
\text { the Organization }\end{array}$} & $\begin{array}{l}\text { 1. Sourcing management develops articulated } \\
\text { strategies for key commodities and purchases. }\end{array}$ & $\begin{array}{l}\text { Carter and Narasimhan (1996), } \\
\text { Zsidisin, Ellram, and Ogden (2003) }\end{array}$ \\
\hline & $\begin{array}{l}\text { 2. Sourcing strategy is based upon and } \\
\text { supports overall corporate strategy. }\end{array}$ & $\begin{array}{l}\text { Carter and Narasimhan (1996), } \\
\text { Carr and Smeltzer (1999), } \\
\text { Ellram, Zsidsin, Siferd, and Stanly (2002), } \\
\text { Zsidisin, Ellram, and Ogden (2003) }\end{array}$ \\
\hline & $\begin{array}{l}\text { 3. Sourcing strategies for common } \\
\text { products/services are coordinated across } \\
\text { business units and executed jointly. }\end{array}$ & $\begin{array}{l}\text { Carter and Narasimhan (1996), } \\
\text { Zsidisin, Ellram, and Ogden (2003) }\end{array}$ \\
\hline & $\begin{array}{l}\text { 4. Vendor Managed Inventory (VMI) is a } \\
\text { component of strategic sourcing. }\end{array}$ & Gumus, Jewkes, and Bookbinder (2008), \\
\hline & $\begin{array}{l}\text { 5. Overall integration of supply chain } \\
\text { initiative is important to the organization. }\end{array}$ & $\begin{array}{l}\text { Carr and Pearson (1999), } \\
\text { Ellram, Zsidsin, Siferd, and Stanly (2002), }\end{array}$ \\
\hline \multirow{3}{*}{$\begin{array}{l}\text { Importance of Supply Chain } \\
\text { Management within the } \\
\text { Organization }\end{array}$} & $\begin{array}{l}\text { 1. Sourcing management is accountable for } \\
\text { specific, measurable goals. }\end{array}$ & $\begin{array}{l}\text { Ellram, Zsidsin, Siferd, and Stanly (2002), } \\
\text { Zsidisin, Ellram, and Ogden (2003) }\end{array}$ \\
\hline & $\begin{array}{l}\text { 2. Sourcing goals are well understood and } \\
\text { visible throughout the entire organization. }\end{array}$ & $\begin{array}{l}\text { Ellram, Zsidsin, Siferd, and Stanly (2002), } \\
\text { Zsidisin, Ellram, and Ogden (2003) }\end{array}$ \\
\hline & $\begin{array}{l}\text { 3. Education in supply chain is important to } \\
\text { the organization. }\end{array}$ & $\begin{array}{l}\text { Carter and Narasimhan (1996), } \\
\text { Nelson, Mayo, and Moody (1998), }\end{array}$ \\
\hline \multirow[t]{3}{*}{$\begin{array}{l}\text { Accountability within the } \\
\text { Organization }\end{array}$} & $\begin{array}{l}\text { 1. Sourcing management goals are well } \\
\text { understood and visible throughout the } \\
\text { sourcing management function. }\end{array}$ & $\begin{array}{l}\text { Carter and Narasimhan (1996), } \\
\text { Zsidisin, Ellram, and Ogden (2003) }\end{array}$ \\
\hline & $\begin{array}{l}\text { 2. Sourcing management goals and actual } \\
\text { performance are reported to top management. }\end{array}$ & $\begin{array}{l}\text { Carter and Narasimhan (1996), } \\
\text { Ellram, Zsidsin, Siferd, and Stanly (2002), } \\
\text { Zsidisin, Ellram, and Ogden (2003) }\end{array}$ \\
\hline & $\begin{array}{l}\text { 3. Sourcing management is accountable for } \\
\text { continuous improvement. }\end{array}$ & $\begin{array}{l}\text { Ellram, Zsidsin, Siferd, and Stanly (2002), } \\
\text { Zsidisin, Ellram, and Ogden (2003) }\end{array}$ \\
\hline \multirow[t]{3}{*}{$\begin{array}{l}\text { Total Cost of } \\
\text { Ownership(TCO) }\end{array}$} & $\begin{array}{l}\text { 1. The cost of diversity in supplier selection is } \\
\text { included in total cost of ownership. }\end{array}$ & $\begin{array}{l}\text { Adobor and McMullen (2007), } \\
\text { Whifield and Landeros (2006), } \\
\text { Shah and Ram (2006) }\end{array}$ \\
\hline & $\begin{array}{l}\text { 2. The cost of environmental innovation is } \\
\text { included in the total cost of ownership. }\end{array}$ & $\begin{array}{l}\text { Gonzalez-Padron, Hult, and Calantone } \\
(2008) \text {, }\end{array}$ \\
\hline & $\begin{array}{l}\text { 3. Supplier ethics management (SEM) is an } \\
\text { important component of sourcing in } \\
\text { determining total cost of ownership. }\end{array}$ & $\begin{array}{l}\text { Gunlach and Murphy (1993), } \\
\text { Landeros and Frank (1996), } \\
\text { Carter (2000 \& 2005), } \\
\text { Cooper, Frank, and Kemp (2000), } \\
\text { Carson (2003), } \\
\text { Fassin (2005), } \\
\text { Bendixen and Abratt (2007), } \\
\text { Bendixen, Abratt, and Jones (2007), } \\
\text { Integrity Interactive (2007), } \\
\text { Industryweek.com (2008), } \\
\text { Gonzalez-Padron, Hult, and Calantone (2008) }\end{array}$ \\
\hline \multirow[t]{4}{*}{ Supplier Analysis } & $\begin{array}{l}\text { 1. Quality is an important component in } \\
\text { sourcing. }\end{array}$ & $\begin{array}{l}\text { Newman and McKeller (1995), } \\
\text { Carter and Narasimhan (1996), } \\
\text { Kaynak (1997), } \\
\text { Degraeve and Roodhooft (1999), } \\
\text { Leong and Stringfellow, Teagarden, and Nie } \\
\text { (2007) }\end{array}$ \\
\hline & $\begin{array}{l}\text { 2. Vendor certification is used as a guide for } \\
\text { the supplier relationship. }\end{array}$ & Carter and Narasimhan (1996), \\
\hline & $\begin{array}{l}\text { 3. Reducing the supplier base is important in } \\
\text { sourcing. }\end{array}$ & Degraeve and Roodhooft (1999) \\
\hline & $\begin{array}{l}\text { 4. Sourcing management has cost targets for } \\
\text { purchases based on the projected selling price } \\
\text { and profit goals for the organization's new } \\
\text { products/services. }\end{array}$ & $\begin{array}{l}\text { Newman and McKeller (1995), } \\
\text { Ellram (1996), } \\
\text { Zsidisin, Ellram, and Ogden (2003) }\end{array}$ \\
\hline
\end{tabular}


Table 2. Perceptions Regarding Sourcing

\begin{tabular}{|c|c|c|c|c|c|c|}
\hline \multicolumn{7}{|c|}{ All Respondents } \\
\hline & \multicolumn{6}{|c|}{ \% Response Distribution } \\
\hline & \multicolumn{3}{|c|}{ Manufacturing } & \multicolumn{3}{|c|}{ Services } \\
\hline & 1-3 & 4 & $5-7$ & 1-3 & 4 & $5-7$ \\
\hline $\begin{array}{l}\text { Compared to } 2008 \text {, business prospects in your organization } \\
\text { for the year } 2009 \text { were: (Q1) }\end{array}$ & 59 & 9 & 32 & 49 & 14 & 37 \\
\hline $\begin{array}{l}\text { Sourcing management develops articulated strategies for } \\
\text { key commodities and purchases. (Q2) }\end{array}$ & 7 & 23 & 75 & 19 & 28 & 53 \\
\hline $\begin{array}{l}\text { Sourcing strategy is based upon and supports overall } \\
\text { corporate strategy. (Q3) }\end{array}$ & 9 & 9 & 82 & 12 & 14 & 74 \\
\hline $\begin{array}{l}\text { Sourcing strategies for common products/services are } \\
\text { coordinated across business units and executed jointly. (Q4) }\end{array}$ & 13 & 12 & 75 & 26 & 11 & 63 \\
\hline $\begin{array}{l}\text { Overall integration of supply chain initiative is important to } \\
\text { the organization. (Q5) }\end{array}$ & 9 & 9 & 82 & 12 & 20 & 68 \\
\hline $\begin{array}{l}\text { Vendor Managed Inventory (VMI) is a component of } \\
\text { strategic sourcing. (Q6) }\end{array}$ & 21 & 15 & 64 & 15 & 12 & 73 \\
\hline $\begin{array}{l}\text { Sourcing management is viewed as an important function } \\
\text { by other functional areas within the organization. (Q7) }\end{array}$ & 20 & 14 & 66 & 25 & 19 & 56 \\
\hline $\begin{array}{l}\text { Sourcing goals are well understood and visible throughout } \\
\text { the entire organization. (Q8) }\end{array}$ & 29 & 16 & 55 & 36 & 15 & 49 \\
\hline $\begin{array}{l}\text { Education in supply chain is important to the } \\
\text { organization.(Q9) }\end{array}$ & 18 & 12 & 70 & 14 & 13 & 73 \\
\hline $\begin{array}{l}\text { Sourcing management is accountable for specific, } \\
\text { measurable goals. (Q10) }\end{array}$ & 13 & 10 & 77 & 22 & 14 & 64 \\
\hline $\begin{array}{l}\text { Sourcing management goals are well understood and visible } \\
\text { throughout the sourcing management function. (Q11) }\end{array}$ & 21 & 11 & 68 & 25 & 19 & 56 \\
\hline $\begin{array}{l}\text { Sourcing management goals and actual performance are } \\
\text { reported to top management. (Q12) }\end{array}$ & 9 & 11 & 80 & 19 & 8 & 73 \\
\hline $\begin{array}{l}\text { Sourcing management is accountable for continuous } \\
\text { improvement. (Q13) }\end{array}$ & 14 & 16 & 70 & 19 & 14 & 67 \\
\hline $\begin{array}{l}\text { Sourcing management communicates cost savings to top } \\
\text { management in a manner that aligns the savings with key } \\
\text { corporate goals and objectives. (Q14) }\end{array}$ & 11 & 14 & 75 & 14 & 26 & 60 \\
\hline $\begin{array}{l}\text { Risk assessment is an important component in sourcing. } \\
\text { (Q15) }\end{array}$ & 7 & 14 & 79 & 8 & 11 & 81 \\
\hline Social responsibility is important to the organization. (Q16) & 13 & 7 & 80 & 7 & 13 & 81 \\
\hline Supplier reliability is important to the organization. (Q17) & 0 & 7 & 93 & 0 & 7 & 93 \\
\hline
\end{tabular}




\begin{tabular}{|c|c|c|c|c|c|c|}
\hline $\begin{array}{l}\text { Sourcing performance objectives are based on total cost of } \\
\text { ownership.(Q18) }\end{array}$ & 16 & 14 & 70 & 15 & 25 & 60 \\
\hline $\begin{array}{l}\text { Total cost of ownership is a well-understood and accepted } \\
\text { measurement tool within the organization. (Q19) }\end{array}$ & 23 & 16 & 61 & 33 & 23 & 44 \\
\hline $\begin{array}{l}\text { Total cost of ownership is a well-understood and accepted } \\
\text { measurement tool within the sourcing function. (Q20) }\end{array}$ & 18 & 14 & 68 & 34 & 25 & 41 \\
\hline $\begin{array}{l}\text { Key supplier selection decisions are based on total cost of } \\
\text { ownership rather than price.(Q21) }\end{array}$ & 27 & 19 & 54 & 40 & 15 & 45 \\
\hline $\begin{array}{l}\text { The cost of diversity in supplier selection is included in } \\
\text { total cost of ownership. (Q22) }\end{array}$ & 23 & 22 & 55 & 41 & 25 & 34 \\
\hline $\begin{array}{l}\text { The cost of environmental innovation is included in the } \\
\text { total cost of ownership. (Q23) }\end{array}$ & 29 & 32 & 39 & 34 & 24 & 42 \\
\hline $\begin{array}{l}\text { Supplier ethics management (SEM) is an important } \\
\text { component of sourcing in determining total cost of } \\
\text { ownership. (Q24) }\end{array}$ & 20 & 16 & 64 & 19 & 23 & 58 \\
\hline $\begin{array}{l}\text { Sourcing Management develops breakdowns of a supplier's } \\
\text { cost structure for key purchases.(Q25) }\end{array}$ & 18 & 18 & 64 & 16 & 28 & 56 \\
\hline $\begin{array}{l}\text { Sourcing management works with suppliers to encourage } \\
\text { them to disclose their costs and cost structures. (Q26) }\end{array}$ & 20 & 19 & 61 & 23 & 17 & 60 \\
\hline $\begin{array}{l}\text { Sourcing management and suppliers work together to take } \\
\text { costs out of products and services. (Q27) }\end{array}$ & 14 & 13 & 73 & 16 & 22 & 62 \\
\hline $\begin{array}{l}\text { Sourcing management develops a database of estimated } \\
\text { supplier cost structures to use when needed (sometimes } \\
\text { referred to as cost tables). (Q28) }\end{array}$ & 25 & 27 & 48 & 29 & 18 & 53 \\
\hline $\begin{array}{l}\text { Supplier relationships are important to the } \\
\text { organization.(Q29) }\end{array}$ & 2 & 2 & 96 & 0 & 7 & 93 \\
\hline Quality is an important component in sourcing. (Q30) & 0 & 4 & 96 & 1 & 7 & 92 \\
\hline $\begin{array}{l}\text { Vendor certification is used as a guide for the supplier } \\
\text { relationship. (Q31) }\end{array}$ & 13 & 14 & 73 & 22 & 16 & 62 \\
\hline Reducing the supplier base is important in sourcing. (Q32) & 23 & 18 & 59 & 16 & 28 & 56 \\
\hline $\begin{array}{l}\text { Sourcing management has cost targets for purchases based } \\
\text { on the projected selling price and profit goals for the } \\
\text { organization's new products/services.(Q33) }\end{array}$ & $\begin{array}{l}1 \\
23\end{array}$ & 18 & 59 & 21 & 20 & 59 \\
\hline $\begin{array}{l}\text { Sourcing management has cost targets for purchases based } \\
\text { on the projected selling price and profit goals for the } \\
\text { organization's existing products and services.(Q34) }\end{array}$ & 21 & 13 & 66 & 21 & 19 & 60 \\
\hline $\begin{array}{l}\text { Off shoring is an important component of determining } \\
\text { costs.(Q35) }\end{array}$ & 25 & 16 & 59 & 29 & 26 & 45 \\
\hline
\end{tabular}


Table 3. Converging Perceptions Regarding Sourcing

\begin{tabular}{|c|c|c|c|c|c|c|}
\hline \multirow[t]{2}{*}{ Item } & MNF & & SVS & & & \\
\hline & Mean & $\begin{array}{l}\text { Std. } \\
\text { Dev. }\end{array}$ & Mean & $\begin{array}{l}\text { Std. } \\
\text { Dev. }\end{array}$ & t-val. & $\mathrm{P} * *$ \\
\hline $\begin{array}{l}\text { Compared to } 2008 \text {, business prospects in your } \\
\text { organization for the year } 2009 \text { were: }(Q 1)\end{array}$ & 3.41 & 1.75 & 3.70 & 1.74 & -0.93 & 0.35 \\
\hline $\begin{array}{l}\text { Sourcing strategy is based upon and supports } \\
\text { overall corporate strategy. (Q3) }\end{array}$ & 5.33 & 1.45 & 5.17 & 1.57 & 0.58 & 0.56 \\
\hline $\begin{array}{l}\text { Sourcing strategies for common } \\
\text { products/services are coordinated across } \\
\text { business units and executed jointly. (Q4) }\end{array}$ & 5.19 & 1.67 & 4.63 & 1.75 & 1.79 & 0.07 \\
\hline $\begin{array}{l}\text { Vendor Managed Inventory (VMI) is a } \\
\text { component of strategic sourcing. (Q6) }\end{array}$ & 5.04 & 1.86 & 5.03 & 1.71 & 0.23 & 0.98 \\
\hline $\begin{array}{l}\text { Sourcing management is viewed as an } \\
\text { important function by other functional areas } \\
\text { within the organization.(Q7) }\end{array}$ & 4.96 & 1.75 & 4.45 & 1.57 & 1.72 & 0.08 \\
\hline $\begin{array}{l}\text { Sourcing goals are well understood and visible } \\
\text { throughout the entire organization. (Q8) }\end{array}$ & 4.38 & 1.66 & 4.14 & 1.67 & 0.78 & 0.43 \\
\hline $\begin{array}{l}\text { Education in supply chain is important to the } \\
\text { organization.(Q9) }\end{array}$ & 5.05 & 1.65 & 5.11 & 1.56 & -0.20 & 0.84 \\
\hline $\begin{array}{l}\text { Sourcing management goals are well } \\
\text { understood and visible throughout the sourcing } \\
\text { management function. (Q11) }\end{array}$ & 4.98 & 1.65 & 4.62 & 1.68 & 1.23 & 0.22 \\
\hline $\begin{array}{l}\text { Sourcing management is accountable for } \\
\text { continuous improvement. (Q13) }\end{array}$ & 5.18 & 1.69 & 4.78 & 1.58 & 1.33 & 0.09 \\
\hline $\begin{array}{l}\text { Risk assessment is an important component in } \\
\text { sourcing. (Q15) }\end{array}$ & 5.59 & 1.35 & 5.61 & 1.28 & -0.9 & 0.92 \\
\hline $\begin{array}{l}\text { Social responsibility is important to the } \\
\text { organization. (Q16) }\end{array}$ & 5.41 & 1.49 & 5.43 & 1.34 & -0.1 & 0.92 \\
\hline $\begin{array}{l}\text { Supplier reliability is important to the } \\
\text { organization. (Q17) }\end{array}$ & 6.28 & .91 & 6.23 & .85 & 0.29 & 0.77 \\
\hline $\begin{array}{l}\text { Sourcing performance objectives are based on } \\
\text { total cost of ownership.(Q18) }\end{array}$ & 5.08 & 1.59 & 4.91 & 1.46 & 0.63 & 0.52 \\
\hline $\begin{array}{l}\text { Total cost of ownership is a well-understood } \\
\text { and accepted measurement tool within the } \\
\text { organization. (Q19) }\end{array}$ & 4.55 & 1.54 & 4.14 & 1.65 & 1.43 & 0.15 \\
\hline $\begin{array}{l}\text { Key supplier selection decisions are based on } \\
\text { total cost of ownership rather than price.(Q21) }\end{array}$ & 4.64 & 1.70 & 4.23 & 1.86 & 1.30 & 0.19 \\
\hline $\begin{array}{l}\text { The cost of environmental innovation is } \\
\text { included in the total cost of ownership. (Q23) }\end{array}$ & 4.16 & 1.49 & 3.90 & 1.68 & 0.92 & 0.35 \\
\hline $\begin{array}{l}\text { Supplier ethics management (SEM) is an } \\
\text { important component of sourcing in } \\
\text { determining total cost of ownership. (Q24) }\end{array}$ & 4.82 & 1.62 & 4.68 & 1.73 & 0.45 & 0.65 \\
\hline $\begin{array}{l}\text { Sourcing Management develops breakdowns of } \\
\text { a supplier's cost structure for key } \\
\text { purchases.(Q25) }\end{array}$ & 4.73 & 1.48 & 4.67 & 1.58 & 0.20 & 0.84 \\
\hline $\begin{array}{l}\text { Sourcing management works with suppliers to } \\
\text { encourage them to disclose their costs and cost } \\
\text { structures. (Q26) }\end{array}$ & 4.75 & 1.69 & 4.56 & 1.63 & 0.61 & 0.54 \\
\hline $\begin{array}{l}\text { Sourcing management develops a database of } \\
\text { estimated supplier cost structures to use when } \\
\text { needed (sometimes referred to as cost tables). } \\
\text { (Q28) }\end{array}$ & 4.51 & 1.74 & 4.46 & 1.73 & 0.14 & 0.88 \\
\hline
\end{tabular}




\begin{tabular}{|c|c|c|c|c|c|c|}
\hline $\begin{array}{l}\text { Supplier relationships are important to the } \\
\text { organization.(Q29) }\end{array}$ & 6.23 & & 6.26 & & -0.22 & 0.82 \\
\hline $\begin{array}{l}\text { Quality is an important component in sourcing. } \\
\text { (Q30) }\end{array}$ & 6.39 & 0.80 & 6.32 & 0.95 & 0.44 & 0.65 \\
\hline $\begin{array}{l}\text { Vendor certification is used as a guide for the } \\
\text { supplier relationship. (Q31) }\end{array}$ & 5.25 & 1.45 & 4.73 & 1.73 & 1.83 & 0.06 \\
\hline $\begin{array}{l}\text { Reducing the supplier base is important in } \\
\text { sourcing. (Q32) }\end{array}$ & 4.65 & 1.65 & 4.62 & 1.49 & 0.122 & 0.90 \\
\hline $\begin{array}{l}\text { Sourcing management has cost targets for } \\
\text { purchases based on the projected selling price } \\
\text { and profit goals for the organization's new } \\
\text { products/services.(Q33) }\end{array}$ & 4.85 & 1.88 & 4.75 & 1.63 & 0.34 & 0.73 \\
\hline $\begin{array}{l}\text { Sourcing management has cost targets for } \\
\text { purchases based on the projected selling price } \\
\text { and profit goals for the organization's existing } \\
\text { products and services.(Q34) }\end{array}$ & 4.95 & & 4.73 & & 0.70 & 0.48 \\
\hline $\begin{array}{l}\text { Off shoring is an important component of } \\
\text { determining costs.(Q35) }\end{array}$ & 4.78 & 1.97 & 4.25 & 1.74 & 1.58 & 0.11 \\
\hline $\begin{array}{l}\text { * Sample size is } 57 \text { and } 73 \text { for manufacturing } \\
\text { and services firms, respectively. }\end{array}$ & & & & & & \\
\hline
\end{tabular}

Table 4. Significant Perception Differences Regarding Sourcing

\begin{tabular}{|l|l|l|l|l|l|l|}
\hline & MNF & & SVS & & & \\
\cline { 2 - 7 } & Mean & Std. & Mean & Std. & t-val. & P** \\
Dev. & & & \\
\hline $\begin{array}{l}\text { Sourcing management develops articulated } \\
\text { strategies for key commodities and purchases. (Q2) }\end{array}$ & 5.28 & 1.42 & 4.58 & 1.57 & 2.62 & 0.01 \\
\hline $\begin{array}{l}\text { Overall integration of supply chain initiative is } \\
\text { important to the organization. (Q5) }\end{array}$ & 5.85 & 1.50 & 5.24 & 1.61 & 2.17 & 0.03 \\
\hline $\begin{array}{l}\text { Sourcing management is accountable for specific, } \\
\text { measurable goals. (Q10) }\end{array}$ & 5.41 & 1.64 & 4.76 & 1.67 & 2.21 & 0.03 \\
\hline $\begin{array}{l}\text { Sourcing management goals and actual performance } \\
\text { are reported to top management. (Q12) }\end{array}$ & 5.69 & 1.57 & 5.03 & 1.63 & 2.31 & 0.02 \\
\hline $\begin{array}{l}\text { Sourcing management communicates cost savings } \\
\text { to top management in a manner that aligns the } \\
\text { savings with key corporate goals and objectives. } \\
\text { (Q14) }\end{array}$ & 5.47 & 1.55 & 4.75 & 1.52 & 2.63 & 0.009 \\
\hline $\begin{array}{l}\text { Total cost of ownership is a well-understood and } \\
\text { accepted measurement tool within the sourcing } \\
\text { function. (Q20) }\end{array}$ & 4.89 & 1.53 & 4.10 & 1.67 & 2.78 & 0.006 \\
\hline $\begin{array}{l}\text { The cost of diversity in supplier selection is } \\
\text { included in total cost of ownership. (Q22) }\end{array}$ & 4.54 & 1.36 & 3.74 & 1.71 & 2.58 & 0.01 \\
\hline $\begin{array}{l}\text { Sourcing management and suppliers work together } \\
\text { to take costs out of products and services. (Q27) }\end{array}$ & 5.3 & 1.50 & 4.7 & 1.46 & 2.28 & 0.02 \\
\hline $\begin{array}{l}* \text { Sample size is 57 and 73 for manufacturing and } \\
\text { services firms, respectively. }\end{array}$ & & & & & & \\
\hline
\end{tabular}




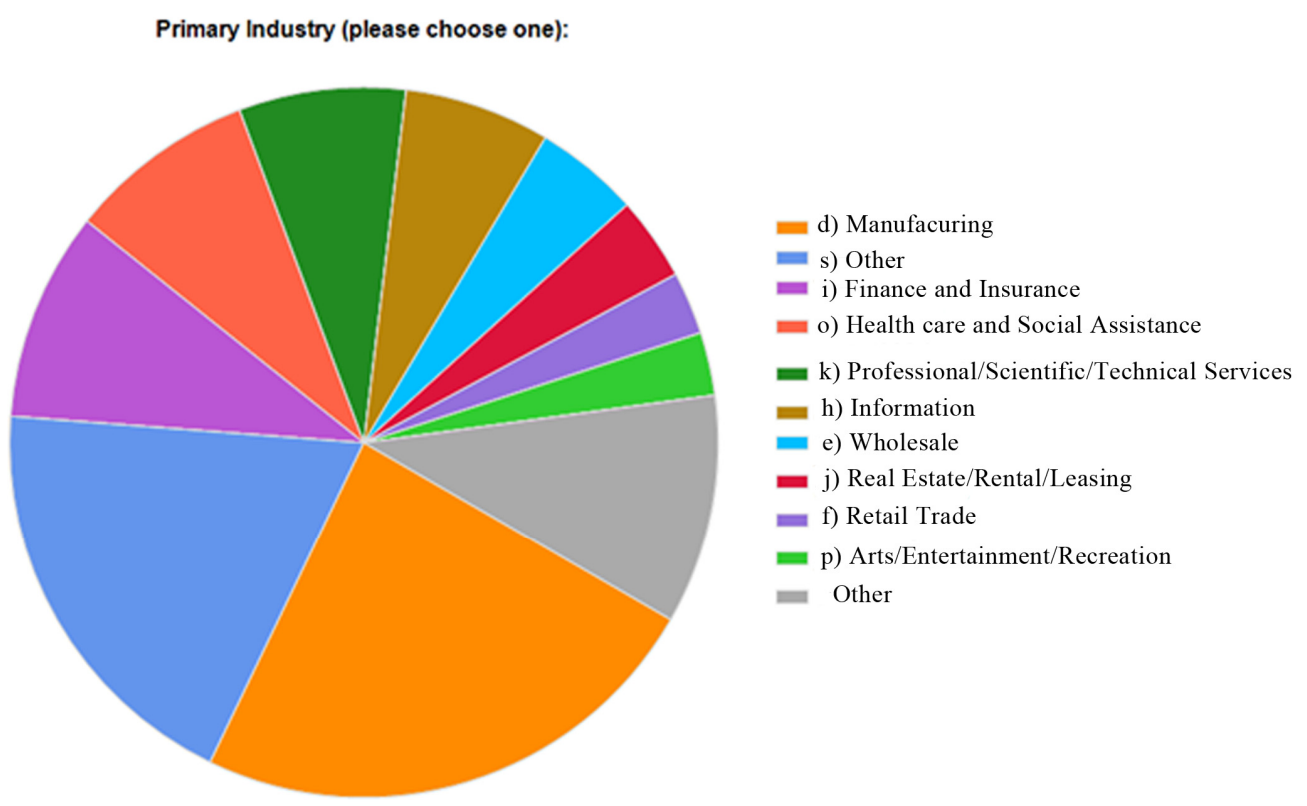

Figure 1. Primary Industry (please choose one)

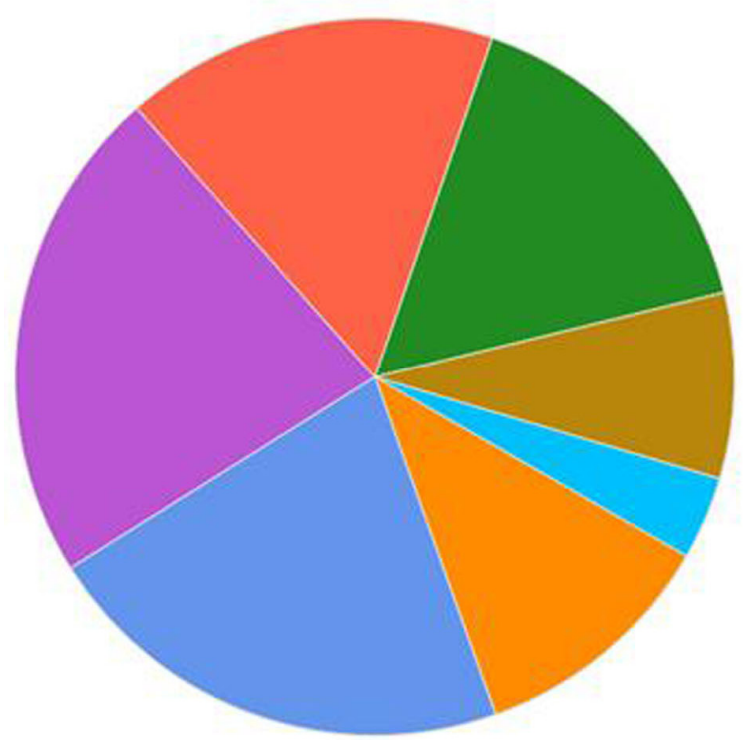

-a. Lower by less than $10 \%$

- b. Lower by $10 \%$ to $20 \%$

- c. Lower by more than $20 \%$

$=\mathrm{d}$. Unchanged

- e. Higher by less than $10 \%$

= f. Higher by $10 \%$ to $20 \%$

- g. Higher by more than $20 \%$ higher

Figure 2. Estimated purchases in your organization (for financial year 2009) 